\title{
Relationship between VAK Learning Styles and Problem Solving Styles regarding Gender and Students' Fields of Study
}

\author{
Shahin Gholami \\ Islamic Azad University, Shiraz, Iran \\ Mohammad S. Bagheri \\ Islamic Azad University, Shiraz, Iran
}

\begin{abstract}
This study aimed to identify VAK learning styles and problem solving styles of students, to check the relationship between these and to investigate the differences in the above-mentioned styles between male and female students and their fields of study. To this end, 102 students were selected through convenient sampling from Boushehr Islamic Azad University (Iran). Reid's learning style and Cassidy and Long's problem solving style questionnaires were administered to the sample. The data gathered were subjected to the statistical procedure of Pearson Product Moment correlation, two way repeated measures ANOVA, and Independent sample $t$-test. The results indicated that there is a positive relationship between VAK learning styles and problem solving styles. The results also showed that fields of study did not have an effect on VAK learning styles and problem solving styles. Further, it was found that gender has no effect on VAK learning styles, but it has an effect on problem solving styles.
\end{abstract}

Index Terms—-problem solving styles, VAK learning styles, fields of study, gender

\section{INTRODUCTION}

In the study, two variables were used; the first one was VAK learning styles, the original VAK concepts were first developed by psychologists and child teaching specialists such as Fernald, Keller, Orton, Gillingham, Stillman and Montessori, starting in the 1920's. VAK theory is now a favorite of the accelerated learning community because its principles and benefits extend to all types of learning and development, far beyond its early applications. The VisualAuditory-Kinesthetic learning style model does not overlay Gardner's multiple intelligences, or Kolb's theory; rather the VAK model provides a different perspective for understanding and explaining a person's preferred or dominant thinking and learning style, and strengths. Gardner's theory is one way of looking at learning styles; Kolb and VAK are still other ways. The VAK learning style uses the three main sensory receivers: Visual, Auditory, and Kinesthetic to determine the dominant learning style, and it is sometimes known as VAKT (Visual, Auditory, Kinesthetic, \& Tactile). (Alan Chapman, 2005-2012)

Visual learners prefer to learn via the visual channel. Therefore, they like to read a lot, which requires concentration and time spent alone. Visual learners need the visual stimulation of bulletin boards, video and movies. They must have written directions if they are to function well in the classroom". (Oxford, 1995, p. 35)

Auditory learners enjoy the oral-aural learning channel. Thus, they want to engage in discussions, conversations, and group work. These students typically require only oral directions". (Oxford, 1995, p. 36)

Kinesthetic learners are those who "imply total physical involvement with a learning environment such as taking a field trip, dramatizing, pantomiming, or interviewing". (Kinsella, 1995, p. 172)

Tactile learners learn with one's hands through manipulation or resources, such as writing, drawing, building a model, or conducting a lab experiment". (Kinsella, 1995, p. 172)

The second variable was problem solving style. Problem solving style has emerged in the literature as an important variable in the development and maintenance of affective disorders. (Cassidy \& Long, 1996). The concept of problem solving style originated in the literature on coping styles (Billings \& Moos, 1981) and was developed through the work of Heppner and Petersen (1982) and Nezu (1987). This study attempted to investigate the relationship between these two variables. It aimed to reveal how gender and fields of study have an effect on these two variables.

\section{STATEMENT Of THE Problem}

Everyone learns in different ways. Some people need to see things (visual style), some need to hear (auditory style), and some need to do something with the things in order to learn them (kinesthetic style). Sometimes not knowing the learning styles may cause anxiety. The present research intends to investigate the relationship between those styles and problem solving styles. The issue of problem solving has attracted the attention of many researchers. The findings show 
that it is not so much important that people face problems and difficulties in their lives, but what is important is to behave correctly when facing problems. Some people are not even able to solve their routine problems and when facing a trivial problem they become embarrassed, upset and tense (Shokohi-Yekta \& Parands, 2008).

\section{PURPOSE OF THE STUDY}

The purpose of this study was to investigate both VAK learning styles of EFL students of Boushehr Azad University and problem solving styles they use. In addition to these, this study aimed at finding out whether there are significant differences in VAK learning styles and problem solving styles according to students' gender and students' fields of study, thus the following research question were formulated:

RQ 1: Is there a relationship between VAK learning style and problem solving style?

RQ 2: Is there a difference in VAK learning style of students based on their gender?

RQ 3: Is there a difference in problem solving styles of students based on their gender?

RQ 4: What are problem solving styles that are used by students based on their fields of study?

RQ 5: Which methods of VAK learning style are used by students based on their fields of study?

\section{REVIEW OF LITERATURE}

Much research has been done on learning style preferences in different sex, level, and fields of study. Chemistry curriculum, physiology courses, nursing and midwifery courses, and occupational therapy are some of the courses, in which research has been done. The present study has been done on different fields of study. Political sciences, laws, economics are the new courses for learning style preferences; and as for problem solving styles, most of the research, is in psychology and medicine domain and a few in teaching. In the following paragraphs, different research on learning styles and problem solving styles will be explained.

Dobson (2010) compared learning style preferences and sex and course performance. His results showed that there was a relationship between learning style and sex and course performance, and also Bidabadi and Yamat (2010) did a study on learning style preferences. The results demonstrated that there was no statistically significant difference between the mean scores of male and female students' learning style preferences (Bidabadi, F. SH., \&Yamat, H. (2010)). Mulalic, Mohd Shah, and Ahmad (2009) attempted to determine the learning styles of the students, and the differences in learning styles of the students according to their gender and ethnicity. Results revealed that the students' preferred learning style was Kinesthetic. They expressed minor preference for Visual, and Auditory (Mulalic, A., Mohd Shah, P., \& Ahmad, F. (2009)). Wehrwein, Lujan, and DiCarlo (2007) carried out a research on gender differences in learning style preferences among undergraduate physiology students. Their findings showed that male and female students have significantly different learning styles (Wehrwein, E., Lujan, H., \& DiCarlo, S. (2007)). Bricheno, and Younger, (2004) revealed some unexpected results of a learning styles intervention. The analysis of data from the common VAK questionnaire suggested that contrary to expectations derived from assertions within some of the literature, there was no significant relationship between gender and preferred learning styles. Individual boys did not necessarily prefer a kinesthetic learning style compared to a visual or auditory one; indeed, data from across the four schools reveals that few boys apparently held such preferences and that the proportions of boys and girls identified as having a kinesthetic learning style were very similar (Bricheno, P., \& Younger, M. (2004)).

Mohammadi, Alizadeh, and Sedaghat (2011) did research on divorce and problem solving style. The results revealed that most common problem solving styles among the participants were avoidance, approach and creativity respectively (Mohammadi, R., Alizadeh, KH., \& Sedaghat, M. (2011)). Sarvghad and Dianat (2009) conducted a study aimed at investigating the learning and problem solving styles of university students. The results of the study showed that there was a significant relationship between students' learning styles and their problem solving styles. It was also indicated that there was a significant relationship between students' major and the patterns of use of both learning styles and problem solving styles. Further, it was revealed that there was a statistically significant difference between the pattern of use of problem solving styles of male and female students (Sarvghad, S., \& Dianat, A. S. (2009)). Babapour, RasoulzudehTabaTabei, FathiAshtiani, and Ezhehei (2003) conducted a study on the relationship between problem solving styles and psychological well-Being among university students. They revealed that there is a partial gender difference between males and females in problem solving styles, so that females utilize avoidant problem solving style more than males (Babapour, K. J., RasoulzudehTabaTabei, k., Fathi Ashtiani, A., \& Ezhehei, J. (2003)). Cassidy (2002) investigated the relationship between problem solving style, achievement motivation, psychological distress and effectiveness in an emergency in 107 volunteers in a simulated aircraft disaster. Effectiveness was measured in terms of the speed of egress averaged across four trials and the total number of bonuses earned. The best predictor of speed of egress was problem-solving confidence, while those who earned most bonuses tended to score higher on problem solving creativity, dominance and status aspiration (Cassidy, T. (2002), 325-332).

\section{Methodology}

Population of this study was 102 students of Boushehr Azad University, from this population all subjects were selected through convenient sampling. 


\section{A. Participants}

The participants in this study were one hundred and two EFL learners majoring in political sciences, law, and economics at Boushehr Azad University, Iran. They were 59 male and 43 female freshmen students. The age of the learners ranged between 19 and 34 for political sciences (there were two male students with the age of 44 and 56 in political sciences as outliers), between 18 and 26 for economics, and between 18 and 24 for law (there was one male student with the age of 35 as an outlier). They were all Iranians and participated in this research willingly.

\section{B. Instruments}

Reid's (1987) perceptual learning style preference questionnaire (PLSPQ) was used, according to Almasa Mulalic (2009), Reid's (1987) perceptual learning style preference questionnaire is valid enough to be used in this study. The questionnaire, which was designed and validated for non-native speakers, consists of five statements on each of the six learning styles to be measured: visual, auditory, kinesthetic, tactile, group learning, and individual learning. The first four categories are in the perceptual learning style categories, so they were used for the current study (Reid, 1987). The students responded based on Likert-scale, they chose one of these choices 1-strongly agree, 2-agree, 3-undecided 4disagree, 5-strongly disagree.

Problem solving style questionnaire: this questionnaire which was designed by Cassidy and Long (1996) contains 28 items that have three choices which totally evaluated 7 factors or problem solving styles. These factors are:

1) Helplessness style, which shows that the individual is totally helplessness in problematic situation. 2) Control style that reflects inner-outer in problematic situations.

3) Creative style which show planning and considering various solutions.

4) Confidence style that believes the individual can solve the problem.

5) Avoidance style that reflects ignoring and rejecting the problem rather that facing it.

6) Approach style that shows positive attitude towards problems and tendency to face them.

7) Support Seeking style.

This measure is a useful, valid and reliable instrument to evaluate problem solving styles (Mohammadi, 1997). Mohammadi and Sahebi (2001) reported the reliability of this instrument using Cronbach's alpha coefficient as.66. In a study conducted by Babapoor Kheyrodin and Ezhey (2002) alpha coefficient was equal to .77.

The Persian translations of the questionnaires were used. The translations were done by the researcher, edited by a teacher, then they were back translated from Persian to English by an M.A. student. The researcher compared the translated texts with the original texts and no difference was identified, so the Persian translations of the questionnaires were used.

\section{Procedure}

Students completed both of the questionnaires during class time, they completed them at the same time. At first, students completed the Persian version of the Perceptual Learning style Preference Questionnaire (PLSPQ). There was no time limit for answering the questionnaire. The researcher asked the students to write their age, gender, and major down, because of being important for the research. The researcher administrated the questionnaire herself. She asked the participants to mark one of the choices 1-strongly agree, 2-agree, 3- undecided 4-disagree, 5-strongly disagree. Score 5 was allocated to strongly agree, 4 to agree, 3 to undecided, 2 to disagree, and 1 to strongly disagree.

After completing the first questionnaire, the researcher ask the students to fill in the second questionnaire. The Persian version of the problem solving style questionnaire was given to the students (PSSQ). The participants were asked to mark one of the choices from true to false. Score 3 was allocated to true, 2 to?, and 1 to false.

\section{Data Analyses}

To analyze the results of the first test (PLSPQ), Two way Repeated Measures ANOVA was used; with a Two way Repeated Measures ANOVA, there are three analyses to consider. The main effect for each of the two independent variables and the interaction between them. As Table 1 shows gender and fields of study as independent variables do not have an effect on VAK learning styles, because the $\mathrm{P}$ value is not significant and the interaction was also insignificant, meaning that there is no effect of gender on fields of study or vice-versa.

TABLE 1.

TWO WAY REPEATED MEASURES ANOVA FOR VAK LEARNING STYLES, GENDER, AND FIELDS OF STUDY

\begin{tabular}{|c|c|c|c|c|c|c|}
\hline \multicolumn{2}{|l|}{ Effect } & \multirow{2}{*}{\begin{tabular}{|l|} 
Value \\
.968
\end{tabular}} & \multirow{2}{*}{\begin{tabular}{|l|}
$\mathrm{F}$ \\
$1.032^{\mathrm{a}}$ \\
\end{tabular}} & \multirow{2}{*}{\begin{tabular}{|l} 
Hypothesis df \\
3.000
\end{tabular}} & \multirow{2}{*}{\begin{tabular}{|l|} 
Error df \\
94.000 \\
\end{tabular}} & \multirow{2}{*}{\begin{tabular}{|l} 
Sig. \\
.382
\end{tabular}} \\
\hline VAK components & Wilks' Lambda & & & & & \\
\hline VAK components * sex & Wilks' Lambda & .997 & $.108^{\mathrm{a}}$ & 3.000 & 94.000 & .955 \\
\hline VAK components $*$ Major & Wilks' Lambda & .938 & $1.023^{\mathrm{a}}$ & 6.000 & 188.000 & .412 \\
\hline VAK components $*$ sex $*$ Major & Wilks' Lambda & .967 & $.527^{\mathrm{a}}$ & 6.000 & 188.000 & .787 \\
\hline
\end{tabular}

To analyze the results of the second test (PSSQ), Two way Repeated Measures ANOVA was used; it was found that $\mathrm{P}$ value for problem solving styles is significant, but is unknown whether gender or fields of study have an effect on problem solving styles. So One way ANOVA was used to see the effect of fields of study on problem solving styles, but 
the obtained data revealed that fields of study do not have effect on problem solving styles, and to know which style, gender has effect on, Independent sample $t$-test was carried out. As Table3 shows, control style has a $\mathrm{P}$ vale less than 0.05, which means that gender has an effect on this style, and according to Table 4. male has a higher mean than female, which means that male students have a higher inner-outer control in problematic situations. The interaction between gender and fields of study was not significant, meaning that there is no effect of gender on fields of study or vice-versa.

TABLE 2

TWO WAY REPEATED MEASURES ANOVA FOR PROBLEM SOLVING STYLES, GENDER, AND FIELDS OF STUDY

\begin{tabular}{|l|l|l|l|l|l|l|}
\hline \multicolumn{2}{|l|}{ Effect } & Value & F & Hypothesis df & Error df & Sig. \\
\hline Problem solving & Wilks' Lambda & .288 & $37.407^{\mathrm{a}}$ & 6.000 & 91.000 \\
\hline Problem solving * sex & Wilks' Lambda & .907 & $1.557^{\mathrm{a}}$ & 6.000 & 91.000 \\
\hline Problem solving * Major & Wilks' Lambda & .897 & $.848^{\mathrm{a}}$ & 12.000 & 182.000 & .600 \\
\hline Problem solving * sex * Major & Wilks' Lambda & .828 & $1.505^{\mathrm{a}}$ & 12.000 & 182.000 \\
\hline
\end{tabular}

TABLE 3.

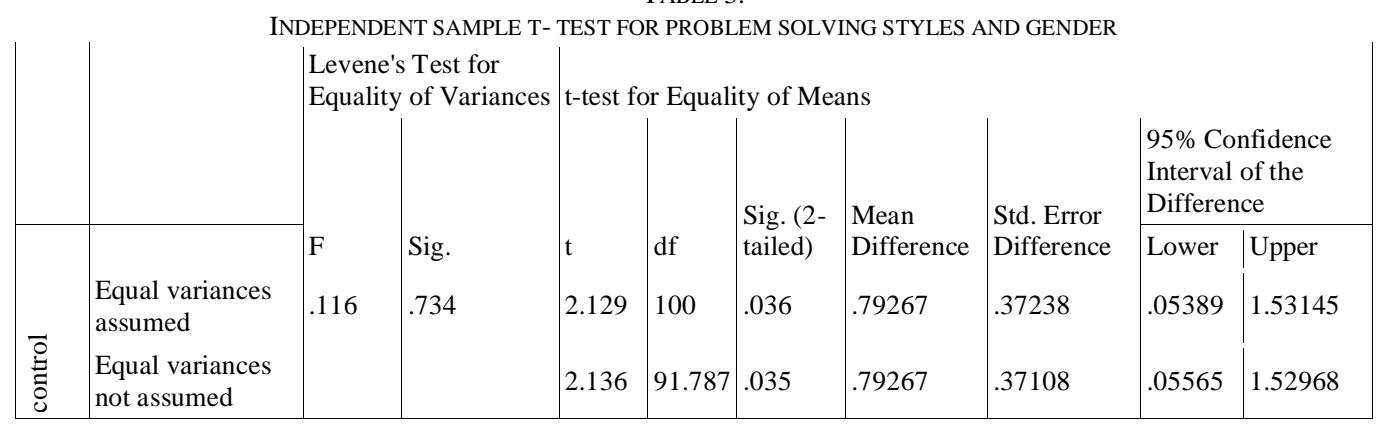

TABLE 4.

\begin{tabular}{|l|l|l|l|l|l|}
\hline \multirow{3}{*}{ control } & Sex & $\mathrm{N}$ & Mean & Std. Deviation & Std. Error Mean \\
& male & 59 & 8.9322 & 1.87418 & .24400 \\
\cline { 2 - 6 } & female & 43 & 8.1395 & 1.83331 & .27958 \\
\hline
\end{tabular}

In order to determine whether there was a statistically meaningful relationship between VAK learning styles and problem solving styles of the students, the Pearson Product Moment correlation was computed.

TABLE5.

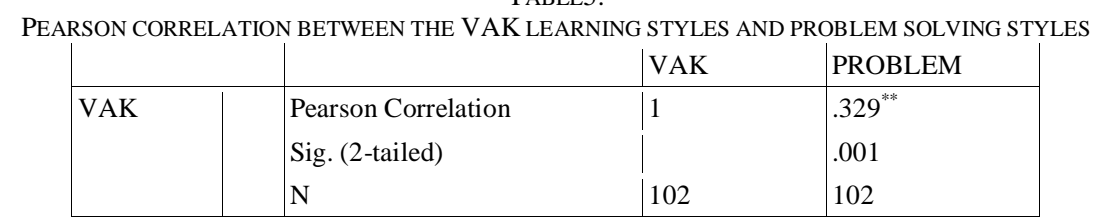

The correlational analyses revealed a positive relationship between VAK learning styles and problem solving styles at the 0.01 level of significance. But Table 5 didn't tell anything about the relationship between the components of VAK learning styles and problem solving styles, so another Pearson Product Moment correlation was used, the results are summed up in Table6. The results revealed that confidence learning style significantly correlated with tactile learning style at $\mathrm{p}<.05$ significance value with Pearson correlation being 0.198 and $\mathrm{p}=0.047$ (see Table 6.). This implies that tactile learners are more confident and can solve the problem when facing a difficult situation.

Creativity learning style significantly correlated with auditory, tactile, and kinesthetic learning styles at $\mathrm{p}<.05$ significance value with Pearson correlation being 0.283(0.004), 0.247(0.012), and 0.287(0.003) respectively (see Table 6.). Therefore, it shows that auditory, tactile and kinesthetic learners plan and consider various solutions when they face a problem. It was also found that there was a significant relationship between avoidance learning style and kinesthetic learning style at $p<.05$ significance level, the correlation coefficient was found $0.226(0.022)$. It means that kinesthetic learners prefer to ignore and reject the problem rather than face it.

The results also indicated that seeking support learning style significantly correlated with auditory, tactile, and kinesthetic learning styles at $\mathrm{p}<.05$ significance value with Pearson correlation being 0.209 (0.035), 0.320 (0.001) , and 0.213 (0.031). Therefore, the results show that auditory, tactile, and kinesthetic learners when facing a problem get help from other people. 
TABLE6.

PEARSON CORRELATION FOR THE RELATIONSHIP BETWEEN THE COMPONENTS OF VAK LEARNING STYLES AND COMPONENTS OF PROBLEM SOLVING STYLES

\begin{tabular}{|c|c|c|c|c|c|}
\hline & & visual & auditory & tactile & kinesthetic \\
\hline \multirow[t]{2}{*}{ helplessness } & Pearson Correlation & .006 & -.178 & -.144 & -.038 \\
\hline & $\mathrm{P}$ & .955 & .073 & .149 & .702 \\
\hline \multirow[t]{2}{*}{ control } & Pearson Correlation & -.075 & .017 & .143 & .085 \\
\hline & $\mathrm{P}$ & .454 & .864 & .153 & .394 \\
\hline \multirow[t]{2}{*}{ confidence } & Pearson Correlation & .176 & .143 & $.198^{*}$ & .176 \\
\hline & $\mathrm{P}$ & .077 & .150 & .047 & .077 \\
\hline \multirow[t]{2}{*}{ creativity } & Pearson Correlation & .017 & $.283^{* *}$ & $.247^{*}$ & $.287^{* *}$ \\
\hline & $\mathrm{P}$ & .867 & .004 & .012 & .003 \\
\hline \multirow[t]{2}{*}{ Avoidance } & Pearson Correlation & .038 & .115 & .141 & $.226^{*}$ \\
\hline & $\mathrm{P}$ & .701 & .249 & .158 & .022 \\
\hline \multirow[t]{2}{*}{ Approach } & Pearson Correlation & .090 & .145 & .100 & .064 \\
\hline & $\mathrm{P}$ & .370 & .147 & .316 & .522 \\
\hline \multirow[t]{2}{*}{ Support Seeking } & Pearson Correlation & .053 & $.209^{*}$ & $.320^{* *}$ & $.213^{*}$ \\
\hline & $\mathrm{P}$ & .599 & .035 & .001 & .031 \\
\hline
\end{tabular}

\section{DISCUSSION}

In this section, reported results are discussed and the research questions are answered. The first question dealt with the relationship between VAK learning styles and problem solving styles. The correlational analysis for VAK learning styles and problem solving styles was carried out and it shows a positive relationship between VAK learning styles and problem solving styles.

To know more about the components of VAK learning styles and problem solving styles, the results are summed up in Table 6. According to this Table, the first component of VAK learning styles is visual style; there is no relationship between this style and the components of problem solving styles. The second style of VAK learning style is auditory style; this style has a positive relationship with Creativity style and Support Seeking. The third style of VAK learning styles is tactile style; this style has a positive relationship with Confidence, Creativity, and Support Seeking styles. The last component of VAK learning styles is kinesthetic style; this style has a positive relationship with Creativity, Avoidance, and Support Seeking styles.

The second question posed in this study, (Is there a difference in VAK learning style of students based on their gender?) is going to be answered and discussed, according to the obtained results. According to Table 1 gender does not have any effects on VAK learning styles.

The third question in this study, (Is there a difference in problem solving styles of students based on their gender?) is answered according to Table 2. It was found that gender has no effect on problem solving styles, except for one style. In all other styles the $\mathrm{P}$ value is bigger than 0.05 . Table 4.3 shows that, control style has a $\mathrm{P}$ vale less than 0.05 , which means that gender has an effect on this style, and according to Table 4, male has a higher mean than that of female.

The fourth question of this study is: What are the problem solving styles that are used by students based on their fields of study? According to Table 2, it can be concluded that fields of study have no effect on problem solving styles, because the $P$ value is bigger than 0.05 in all cases.

The last question, posed in this study, is: Which methods of VAK learning styles are used by students based on their fields of study? It can be concluded that fields of study have no effect on VAK learning styles, because the P value is bigger than 0.05 in all cases based on Table 1.

The last part in discussion section deals with previous research. Dobson (2010) compared learning style preferences and sex and course performance. His results showed that there was a relationship between learning style and sex and course performance, these results also supported the studies done by Wehrwein, Lujan, and DiCarlo (2007),Bricheno, and Younger, (2004), in contrast to this study, Bidabadi and Yamat (2010) found out that there was no statistically significant difference between the mean scores of male and female students' learning style preferences, whose research support the current study. 
Sarvghad and Dianat (2009) revealed that there was a statistically significant difference between the pattern of use of problem solving styles of male and female students, and the study by Babapour, Rasoulzudeh TabaTabei, FathiAshtiani, and Ezhehei (2003) revealed that there is a partial gender difference between males and females in problem solving styles. These two studies share some similar aspects with the current study.

The current study investigated the relationship between VAK learning styles and problem solving styles of university students and the results showed that there was a relationship between VAK learning styles and problem solving styles. This result supported the study conducted by Sarvghad and Dianat (2009). They conducted a study aimed at investigating the learning and problem solving styles of university students. The results indicated that there was a significant relationship between students' learning styles and problem solving styles.

\section{CONCLUSION}

The aim of the study was to investigate the relationship between VAK learning styles and problem solving styles regarding gender and students' fields of study. The results of the study show that there is a positive relationship between VAK learning styles and problem solving styles at the 0.01 level of significance. No statistically significant gender difference in VAK learning style category was found between females and males, but gender has an effect on one style of problem solving styles; Fields of study have no effect on VAK learning styles and problem solving styles.

\section{REFERENCES}

[1] Babapour, K. J., RasoulzudehTabaTabei, k., Fathi Ashtiani, A., \& Ezhehei, J. (2003).Study of relationship between problem solving style and psychological well-Being among university students. Journal of Psychology, 7, 3-16.

[2] Babapoor, K. J., \& Ezheyi, M. J. (2002). The study of relationship between problem solving styles, conflict solving styles, and mental health among Tarbiat Modarres university students. Journal of Psychology, 7, 3-16.

[3] Bidabadi, F. SH., \&Yamat, H. (2010). Learning style preferences by Iranian EFL freshman university students. Procedia Social and Behavioral Sciences, 7, 219-226.

[4] Billings, A.G., \& Moos, R. H. (1981).The role of coping responses and social resources in attenuating the stress of life events. Journal of Behavioral Medicine, 4, 139-157.

[5] Bricheno, P., \& Younger, M. (2004).Some unexpected results of a learning styles intervention. Paper presented BERA conference, September 2004, Manchester, University of Cambridge, Faculty of Education, Hills Road Site: Cambridge.

[6] Cassidy, T. (2002). Problem solving style, achievement motivation, psychological distress and response to a simulated emergency. Counseling Psychology Quarterly, 15, 325-332. Available online: $01 \quad$ Jul 2010. http://www.tandfonline.com/loi/ccpq20.

[7] Cassidy, T., \& Long, C. (1996). Problem solving style, stress and psychological illness: Development of a multifactorial measure. British Journal of Clinical Psychology, 35, 265-277.

[8] Chapman, A. (2005-2012). VAK learning styles. Retrieved September 21, 2011, from www.businessballs.com.

[9] Dobson, L. (2010). A comparison between learning style preferences and sex status, and course performance. Advances in Physiology Education, 34, 197-20.

[10] Heppner, P. P., \& Peterson, C. H. (1982). The development and implications of a personal problem-solving inventory. Journal of Counseling Psychology, 29, 66-75.

[11] Kinsella, K. (1995). Understanding and empowering diverse learners in ESL classrooms. In J. M. Reid (Ed.) Learning styles in the ESL/EFL classroom (170-194). New York: Heinle and Heinle Publishers.

[12] Mohammadi, F. (1997). Comparison of problem solving styles among depressed and normal individuals. Postgraduate Dissertation, Mashhad: Ferdowsi University of Mashhad, unpublished.

[13] Mohammadi, F., \& Sahebi, A. (2001).The study of comparison of problem-solving among depression and normal human. Journal of psychological Sciences, 1, 24-42.

[14] Mohammadi, R., Alizadeh, KH, \& Sedaghat, M. (2011). Need for cognition and problem solving styles in divorce applicant couples and normal couples. Procedia - Social and Behavioral Sciences, 30, 894 - 898.

[15] Mulalic, A., Mohd Shah, P., \& Ahmad, F. (2009). Perceptual learning styles of ESL students. European Journal of Social Sciences, 7.101- 113.

[16] Nezu, A. M. (1987). A problem solving formulation of depression: A literature review and proposal of a pluralistic model. Clinical Psychology Review, 7, 122-144.

[17] Oxford, R. L. (1995). Gender differences in language learning styles: What do they mean? In J. M. Reid (ED.).Learning styles in the ESL/EFL classroom (34-46). New York: Heinlr and Heinle Publishers.

[18] Reid, J. M. (1987). The learning style preferences of ESL students. Tesol Quarterly, 21, 1

[19] Sarvghad, S., \& Dianat, A. S. (2009).A study of learning and problem solving styles of university students. Quarterly Journal of New Approach in Educational Administration, 2, 77-92.

[20] Shokohi, Y. M., \& Parand, A. (2008). The effectiveness of Instruction based on cognitive approach on family relationship. Journal of Family Research, 4, 5-16

[21] Wehrwein, E., Lujan, H., \& DiCarlo, S. (2007). Gender differences in learning style preferences among undergraduate physiology students. Adv Physiology Educ, 31, 153-7. Department of Physiology, Michigan State University, East Lansing, MI, USA. 


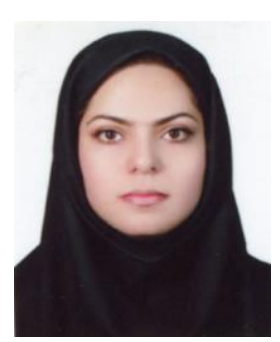

Shahin Gholami holds an M.A in TEFL. She is currently an English teacher at Liyan Institute in Boushehr(Iran). Ms. Gholami defended her thesis in July, 2012 under the supervision of Dr. Bagheri in Islamic Azad University of Shiraz, Iran, entitled: Relationship between VAK Learning Styles and Problem Solving Styles Regarding Gender and Students' Fields of Study.

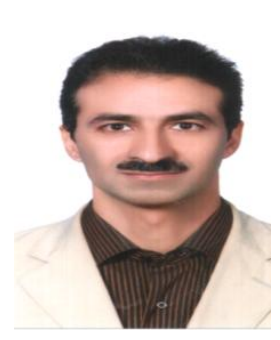

Mohammad S. Bgheri holds a PhD in TEFL. He is currently the Dean of Humanities Faculty at Islamic Azad University, Shiraz, Iran. Dr. Bagheri has published books and articles extensively and has presented a number of articles at local and international conferences. His main interests are international exams, multiple intelligences, learning strategies and assessment. 